\title{
огляд
}

UDC 619:637.513.1 „18-19” (477-25) https://doi.org/10.31548/ujvs2020.04.008

\section{ESTABLISHMENT AND ORGANIZATION OF VETERINARY AND SANITARY SUPERVISION OF KYIV IN THE LATE 19th AND EARLY 20th CENTURY}

M. M. STEHNEI, Candidate of Veterinary Sciences, Associate Professor

Academician V. G. Kasianenko Department of Animal Anatomy,

Histology and Pathomorphology

https://0000-0001-6415-0794

National University of Life and Environmental Sciences of Ukraine, Kyiv, Ukraine

E-mail:Stegney_MM@nubip.edu.ua

Анотація. Information on the formation of veterinary and sanitary supervision in Kyiv since the end of the 19th century is given. By 1888, there were 17 small private abattoirs in Kyiv, scattered throughout the city. The abattoirs were located in yards and dirty barns, where cattle were primitively slaughtered and no importance was attached to veterinary and sanitary supervision. These abattoirs caused great dissatisfaction among the urban population and the Kyiv City Duma decided to close the existing abattoirs and open city abattoirs, i.e. to form a regulated institution that would adhere to highly humane tasks, the responsibility for which is assigned on veterinarians.

To clarify the issues of veterinary and sanitary supervision at city abattoirs in 1899, a special subcommittee was appointed, the chairman of which was elected a member of the Sanitary Commission A. K. Stolpchevskyi. The subcommittee was set a task to develop instructions for veterinarians responsible for the veterinary and sanitary situation at Kyiv city abattoirs, which was carried out by the Sanitary Commission. It was only in 1899 that purely veterinary supervision was separated from sanitary supervision. For the proper organization of veterinary and sanitary supervision in 1909, mandatory resolutions were introduced, which included the rules of arrangement and maintenance of abattoirs. These resolutions introduced a uniform procedure in the abattoir business.

In 1900, the city veterinarian M. K. Kobylyanskyi proposed to expand the veterinary staff in Kyiv and introduce mandatory resolutions on the keeping of farms and dairy cattle. For the first time, in 1901, according to the resolution of the Kyiv Governor, a koumiss and kefir establishment began to function in the village of Pushcha Vodytsia, which was under the subordination of veterinary and sanitary supervision. However, the resolution on 
the supervision of cowsheds, dairy farms, koumiss establishments, and individual farms engaged in the sale of milk and dairy products in Kyiv was issued only in 1916.

Ключові слова: city abattoirs, veterinary and sanitary condition, abattoir business, control and trichinosis station, dairy business

\section{Introduction}

Currently, the state veterinary and sanitary supervision and control over the activities of economic entities for the slaughter of animals, processing, storage, transportation, and sale of products of animal origin (raw materials, food raw materials, by-products, including food) are carried out in accordance with the laws of Ukraine "On the liability of enterprises, institutions and organizations for violations of the legislation on veterinary medicine", "On the quality and safety of food and food raw materials", "On withdrawal from circulation, processing, utilization, destruction or further use of low-quality and dangerous products", rules, instructions, orders, and directives of the Department of Food Safety and Veterinary Medicine of Ukraine, other regulations. According to the legislation of Ukraine, the state veterinary and sanitary supervision and control are carried out by the authorities of public administration, namely: the Department of Food Safety and Veterinary Medicine, and its territorial bodies - the Department of State Food and Consumer Services in the city of Kyiv, cities of regional importance, districts and specially appointed veterinarians who have the powers of the State Food and Consumer Services of Ukraine. Veterinary and sanitary control is also carried out by specialists of veterinary medicine of the economic entities under the direct supervision of official veterinarians. Veterinary measures and veterinary expertise in the procurement and slaughter of ani- mals, trade in meat, meat products, milk, dairy products, etc., as well as supervision over the sanitary condition of trade places in the markets, are under the responsibility of veterinary specialists. Under the Soviet Union, the activities of veterinary specialists were regulated by Veterinary legislation, which included the Veterinary Statute and other legislative acts. In independent Ukraine, in 1999, the State Department of Veterinary Medicine of the Ministry of Agriculture of Ukraine issued "Legislation of Ukraine on veterinary medicine" (Dostoievskyi, 1999). This law includes the general, legal, organizational, and financial foundations of veterinary medicine. It regulates activities in the field of veterinary medicine in accordance with international requirements, recognizes the legal status of veterinary medicine structures, establishes the necessary veterinary and sanitary requirements and the basics of veterinary control.

\section{Results of the research and their discussion}

Until 1885, there was a Sanitary Commission in Kyiv, which consisted of medical doctors and there were no veterinarians. Only in 1885, the Kyiv Governor proposed to include a veterinarian into the Sanitary Commission. The first appointed veterinarian was V. K. Ponomarev (since 1886). With the introduction of this position, the City Sanitary Commission did not determine the scope of activities of the veterinarian. After the dismissal of V. K. Ponomarev, P. M. Genevskyi, who 
previously worked as a senior veterinarian of slaughterhousesabattoirs, was appointed to this position. By 1888 , there were 17 small private slaughterhousesabattoirs in Kyiv, scattered throughout the city and in an unsanitary condition. The slaughterhousesabattoirs were located in yards and dirty barns, where cattle were primitively slaughtered and no importance was attached to veterinary inspection. It was difficult for the veterinary service to deal with the unsanitary conditions of slaughterhousesabattoirs. These slaughterhousesabattoirs caused great dissatisfaction among the urban population and the Kyiv City Duma decided to close the existing slaughterhousesabattoirs and open city slaughterhousesabattoirs, i.e. to form a regulated institution that would adhere to highly human tasks, the responsibility for which is assigned on veterinarians. Veterinarian P. M. Genevskyi, being a member of the Sanitary Commission, noted: "I think it is unnecessary to talk here about the veterinary and sanitary significance of public abattoirs for the population: thousands of annually destroyed diseased organs and carcasses, previously sold and ignorantly eaten, eloquently prove the benefits of this institution, protecting the health of locals" (Otchet, 1894).

Thus, on October 20, 1888, the "Mandatory Resolution on City SlaughterhousesAbattoirs and Their Use" was issued. The Kyiv city slaughterhousesabattoirs were opened on December 17,1888 , located on the street of Velyka Vasylkivska, 137 (Dubrova, 1911), they were built on the model of the St. Petersburg and Odesa slaughterhousesabattoirs, but over time these slaughterhousesabattoirs did not meet the expectations of the Kyiv City Duma and the veterinary service, which was due to non-compliance with veterinary and sanitary requirements and restrictions.
Stopakevich K. E. in the article "Five years (1887-1894) of the Kyiv public abattoirs in the veterinary-sanitary relation" noted that "... city abattoirs are veterinary and sanitary institutions which should serve as a guarantee of good quality and safety for the used edible meat and meat products, to be a bulwark against the spread of epizootics in the city and to be a regulator of the meat trade in the city" (Stopakevych, 1894).

According to the literature (Stopakevych, 1894; Stehney, 2008), the city slaughterhousesabattoirs of the Western European states of Berlin, Vienna, Paris, Strasbourg, Munich, and Leipzig followed the veterinary and sanitary rules. The position of director or inspector of these slaughterhousesabattoirs was held by a veterinarian who dealt with special veterinary and economic issues and was the chief veterinary consultant in the city. In Kyiv, the veterinary staff of the slaughterhousesabattoirs was subordinated to the abattoir manager (not the veterinarian) or the head of the Sanitary Commission (medical doctor). Veterinarians were not members of the Sanitary Commission or Council. Almost all meetings of various commissions were held without the participation of veterinarians. In the case of slaughterhousesabattoirs, the degree of meat quality and the age of the animal were determined not by the Council of different veterinarians, but by the supervisor of the slaughterhousesabattoir activities, who resolved veterinary issues without having a legal right to do so. Accordingly, the veterinarians of the slaughterhousesabattoirs did not perform their professional duties. The Kyiv city slaughterhousesabattoirs from the time of their opening were subordinated to the Public Administration of the city. To improve veterinary affairs in Kyiv city slaughterhousesabattoirs, veterinarians 
advocated subordinating slaughterhousesabattoirs to the Ministry of Internal Affairs: "... city veterinary staff will act more independently..., and public health would be less damaged by the anomalies of sad reality" (Tomylyn, 1892).

This attitude towards veterinary specialists led to the fact that in the summer of 1890, the Kyiv city slaughterhousesabattoirs were left without a single veterinarian (Novyi Kyivskyi yntsydent, 1894).

The premises of the Kyiv city SlaughterhousesaAbattoirs were built of stone, well lit, and spacious. Since the moment of opening (1888), the slaughterhousesabattoirs were divided into four sections: chamber abattoir; pavilion abattoir, or kosher; abattoir for small animals; swine fever and central intestinal tract.

The territory of the Kyiv city Slaughterhousesabattoirs was divided into five sites (yards) where animals were placed. In the animal yards, there were almost 200,000 head of cattle to be slaughtered per year. There was a room for a veterinarian in the № 1 cattle yard. In 1902, this position was held by K. E. Stopakevich. The working day lasted for 10-16 hours, depending on the number of animals delivered for slaughter. The owner of each animal that came in for slaughter was charged a percentage fee. The veterinarian of the abattoir undertook to take into account the receipts of the state interest fee. For the use of the yard at the city abattoirs, the owners of animals were charged: 10 kopecks for a bull, a cow, and a heifer, and 5 kopecks for a calf. If the cattle stayed overnight, the fee was 5 and 3 kopecks, respectively (Uvedomlenye, 1906).

On the territory of the Kyiv city Slaughterhousesabattoirs, there was a trading platform or yard № 2, where cattle were bought and sold. The marketplace of the slaughterhousesabattoirs was not popular with the meat industry, as cattle were brought here for slaughter very exhausted. The best groups of animals were sent to other points of sale, and the Ministry of Internal Affairs decided in 1894 to provide one-time courts for the purchase of livestock through agents directly in the owners' yards in order to support the meat traders.

In the message to the Tambov City Council (dated 23/02/1899), it was noted that there are 5 cattle yards in the Kyiev City Council (Uvedomlenye, 1902).

In yard № 1, the reception of various cattle is carried out. This yard is common for different types of livestock (cattle, cattle, and pigs). Cattle sorting, veterinary inspection, and branding were carried out here. After sorting, cattle entered the yard № 2, calves and small cattle - № 3, pigs - № 4. Yard № 5 was allocated for animals suffering from infectious diseases or suspected forof the disease.

Stopakevych K. E., a veterinarian of the Kyiv Cattle Farm, informed the Kyiv Mayor (1902) that there was a stone room in the Kyiv Abattoir Infectious Disease Yard with two departments: the first one was for animals obviously suffering from infectious diseases; the second - for animals with a plague. A veterinary and police abattoir for slaughtering animals was located near these yards to confirm the diagnosis of the disease.

In 1899,5 veterinarians worked at the Kyiv city Slaughterhousesabattoirs: S. P. Dubrova, M. D. Burlak, F. M. Benevskyi, M. I. Tarakanov, and I. A. Liubimirskyi. This number of veterinarians lasted until 1909. In 1909, 2 more positions of veterinarians were allocated, who replaced paramedics. Dubrov S. P. performed the duties of a senior veterinarian and L. N. Liapunov was in charge of the cattle yard. The remaining 5 doctors (M. D. Burlak, M. I. Tarakanov, M. D. Korotkov, O. I. Kandyba, and 
L. P. Kozhin) headed the abattoirs for cattle and cattle, pig, and horse breeding (Dubrova, 1911). The senior veterinarian, in turn, was in charge of the trichinoscopic station. Almost three years after its opening, in 1891, 125,379 cattle were slaughtered at the Kyiv city abattoirs, of which 14,292 (14\%) were bulls and oxen, $13,698(10.9 \%)$ - cows, and 13,196 $(10.5 \%)$ - calves under two years of age, 13281 (10.6\%) - dairy calves, 46542 (37.1\%) - sheep, 24315 (19.4\%) - pigs, $55(0.04 \%)$ - horses (Tomylyn, 1892). Cattle was delivered to the Kyiv city abattoirs for slaughter from Poltava (44.3\%), Kyiv (43.5\%), Kherson (5.5\%), Chernihiv $(4.5 \%)$, Katerynoslav $(0.9 \%)$, Volyn $(0.7 \%)$, and Podolsk $(0.6 \%)$ provinces.

Veterinarians in urban areas worked in poor conditions. Over the 10 years of its existence, city slaughterhousesabattoirs became famous for their unsanitary condition from which "stench" extended. The newspaper "Kievlianin" noted: "Along the bridge going from the bridge at the entrance to the village of Demievka from the side of Kyiv and to the manor of the state purification wine warehouse is issued such a stench, which can be observed in the most unsanitary landfills. The air contaminated with miasms spreads from here over a long distance around but, above all, such air reaches the estates of the sugar factory and the state wine warehouse, which is known to employ several hundred people" (Ochah zarazy, 1898). When creatingof the Kyiv city slaughterhousesabattoirs, in addition to preventing the pollution of water, soil, and air with slaughterhouse waste, first of all, the task was to provide people with good quality meat. According to archival data (Kyevskye skotoboyny, 1892; Raport, 1899), the wastewater of the Kyiv city slaughterhousesabattoirs descended into the extremely shallow Lybid river, which was saturated with blood until it was red. The sandy bottom of the river was also saturated with blood clots. As noted by veterinarian Vyshnytskyi V. I., the blood flowing into the Lybid river was disinfected with lime but this did not reduce the spread of unpleasant odors beyond the slaughterhousesabattoirs. Containing a scar and excrement entered special pits in the intestinal tract and were taken out in barrels of a sewage convoy outside the city, where they were buried. The city spent up to 6,000 rubles per year on such a procedure.

With the openining of city slaughterhousesabattoirs (according to $\S 1$ of the Mandatory Resolutions of the Duma on Urban SlaughterhousesAbattoirs), a slaughter of cattle was carried out exclusively at city slaughterhousesabattoirs. At the same time, it was not allowed to slaughter even sheep, which was carried out for religious purposes by Muslims living in Kyiv (Korolev, 1914). To do this, a special room was set aside in the city, where sheep were slaughtered for Muslims. Despite the fact that the city slaughterhousesabattoirs were regulated institutions, according to $\S 11$ of these regulations, the owner was allowed to take away the skin, head, and offal no later than 3 hours after the slaughter of livestock. Otherwise, the remains of the slaughter were managed by the administration of slaughterhousesabattoirs. To clarify the issues of veterinary and sanitary affairs on city slaughterhousesabattoirs in 1899, a special subcommittee was allocated, the chairman of which was elected a member of the Sanitary Commission A. K. Stolpchevskyi. The subcommittee was set a task to develope instructions for veterinarians responsible for the veterinary and sanitary situation in Kyiv city SlaughterhousesAabattoirs, 
which was carried out by the Sanitary Commission. It was only in 1899 that purely veterinary supervision was separated from sanitary supervision.

The meeting of the subcommittee raised the question of the need for microscopic examination of meat for trichinosis (Kyevskye skotoboyn, 1899). One of the five veterinarians slaughterhousesabattoirswas appointed to city abattoirs to run the station. With the opening of the microscopic station, the Kyiv city slaughterhousesabattoirs were functionally divided into four departments: trichinosis and microscopic station; cattle and pig abattoir; inspection and branding of imported meat; cattle yard. Independent instructions were developed for the heads of each of these departments. For the proper organization of veterinary and sanitary supervision in 1909 , mandatory regulations were introduced, including rules for the arrangement and maintenance of slaughterhousesabattoirs. These resolutions introduced a uniform procedure in the abattoir business. The significance of this case is evident from the activities of the Kyiv city SlaughterhousesAabattoirs, where in 190916277 cattle, 40043 calves, 264 pigs, 14594 sheep, and 472 horses were slaughtered at the abattoirs in the city's cattle yard. There was a control trichinosis station at the city slaughterhousesabattoirs, the management of which was entrusted to the head of the pig farm. The head was assisted by a senior microscopist, who was appointed by the city council from among the microscopists at the station. All microscopists, including the senior, were subordinated to the head of the slaughterhousesabattoirs. When microscopists detect substandard meat, a senior slaughterhouse veterinarian has been notified for a more detailed examination and decision. A separate microscope and a tool storage box were attached to each microscope. At the same time, the microscopists undertook to keep the microscope properly clean. Butchers brought animals to the Kyiv city slaughterhousesabattoirs. According to the Vilnius City Council, the list of the Kyiv city slaughterhousesabattoirs included 160 Orthodox butchers and 133 Jewish Jews. In order to distinguish imported meat from local meat (slaughtered animals in the Kyiv city abattoirs), two varieties of stamps of different colors were used. Meat from the city was sold better and more expensive than imported meat.

Dr. Rohrbeck's apparatus was used to disinfect finnose, tuberculous, or any other meat. The finnose meat was sterilized for 1 hour, after which it was branded with a special stamp and sent for sale on the market. Carcasses from sick animals were subjected to sterilization against foot and mouth disease, actinomycosis, hemorrhagic septicemia (pasteurellosis), etc. Thus, in 1901-1902, 16 carcasses of cattle, 5 carcasses of calves, 2 carcasses of pig affected by tuberculosis, 99 - foot and mouth disease, 15 - actinomycosis were sterilized. In 1911, a Hennicke system was purchased to sterilize meat. The lard, which was used to prepare soap and ointment, was also subject to sterilization, and the condensed glue obtained from the sterilization was sold to printing houses and mechanical weaving.

With the reappointment of V. K. Ponomarev for the position of a veterinarian in Kyiv (1888), the leading place belongs to veterinary and sanitary supervision, which has been expanding every year. At the same time, considerable attention was paid to the dairy business, supervision of milk and dairy products (Protokol, 1914). At the congress of veterinarians, which took place in Kyiv (1900), there was a report of M. K. Kobylyanskyi "On the importance of veterinary and sanitary super- 
vision of dairy cattle". In his report, the author emphasized the ability of milk and its products to transmit infectious diseases from cows to humans. It should be noted that the Kyiv farms were in the unsanitary state and without the supervision of the veterinarian. Kobylyanskyi M. K. proposed to expand the veterinary staff of Kyiv and introduce a mandatory regulation on the keeping of farms and dairy cattle. To combat tuberculosis, he suggested using tuberculin as a valuable diagnostic tool. The congress decided to recommend the City Administration organize a demonstration farm in the city, where all cows should be tuberculized. Such a demonstration cattle farm was later organized by the city veterinarian M. P. Slesarevskyi. Milk from his farm went to children's institutions.

It should be noted that in Kyiv, a significant percentage of tuberculous cows, whose milk was sold, was diagnosed. During the period from 1885 to 1892 , 4,306 people died from tuberculosis in Kyiv, i.e. almost 539 people a year.

The significant spread of tuberculosis among the population of Kyiv forced the veterinarian V. K. Ponomarev in 1888 to conduct the first census of cattle in Kyiv. Based on this census, the draft "Mandatory Rules for Persons Keeping Cows for Industrial Purposes" was submitted to the Sanitary CommissionIn the same year, for the first time, an examination of a koumiss medical establishment was conducted. Due to lack of funds, dairy farms were inspected 1-2 times a year. The need for such supervision is evidenced by the fact that in 1892 the Sanitary Commission found the funds to pay extra for the inspection of farms for 25 rubles.

Milk in the Kyiv markets was only partially controlled. For sale, milk came extremely contaminated not only with bacteria but also with mechanical impu- rities. Measures to control the milk and dairy products were introduced only in 1913. Permanent and regularly functioning control of milk in Kyiv could not be carried out due to the lack of Mandatory Resolutions on the trade of milk and dairy products in Kyiv, although the need for such regulations was repeatedly discussed at the meetings of the Sanitary Executive Commission and the City Duma in 1902. Veterinarian F. M. Benevskyi even proposed to create a special dairy market in Kyiv, where it was planned to open new positions of veterinarians. Until 1914, the control of milk in the markets was carried out by sanitary doctors.

On January 17, 1914, a meeting of the City Sanitary and Executive Commission on the control of milk entering the markets of Kyiv took place. At this meeting, veterinarian V. K. Korolev raised the issue of milk control from the benches in the chemical department of the sanitary station, equipped with everything necessary for research. In this department, it was proposed to conduct an examination of milk for the percentage of fat, milk falsification, preservatives, contamination, and the presence of leukocytes. The average sample was 1 liter, of which 0.5 liters went to these studies, and 0.5 liters was sent to one of the institutions: Sanitary station for bacteriological examination; Bacteriological Institute of the Society for the Control of Infectious Diseases; District veterinary bacteriological laboratory for research on a microbial count. The cost of milk on the market ranged from 2.5 to 5 kopecks per glass, a "quarter" (2.5-3 liters), depending on the season, cost 18-35 kopecks, a bucket of milk - from 1 ruble 20 kopecks up to 1 ruble 50 kopecks.

During the veterinary and sanitary supervision of milk and dairy products, considerable attention was paid to cowsheds, dairy farms, koumiss establishments. For 
the first time, in 1901, according to the resolution of the Kyiv Governor, in the village of Pushcha Vodytsya, a koumiss and kefir establishment began to function, which was under the subordination of veterinary and sanitary supervision. It should be noted that the sale of these products was allowed by the Sanitary Commission only after examination of mares by a veterinarian.

Most "farmers" in Kyiv kept cows in rented premises, for which they paid high rents. In 1913, a survey of cowsheds was carried out in Kyiv, where $29 \%$ of cowsheds were found to be heavily contaminated, $49 \%$ were of medium purity and only $21 \%$ were clean. Most of the cowsheds were old barns made of planks with slots, without filling, etc. The productivity of cows was not high. They gave from 3 to 10 liters of milk per day. In 1916, they issued "Mandatory regulations on the supervision of cowsheds, dairy farms, koumiss establishments and individual farms selling milk and dairy products in Kyiv" (The project of these resolutions was issued in 1914). At that time, cowsheds, dairy farms, and etc. were farms, in which two or more cows were kept for the purpose of selling milk and dairy products. In Kyiv, most cowsheds and farms kept 2 to 8 cows. There were $73 \%$ of such cowsheds. There were only twenty large farms with more than 10 cows. The opening of the cowsheds required the permission of the City Council, which appointed a special commission to inspect the cowshed, which included the city district veterinarian, the city sanitary doctor, and a police officer. Upon obtaining permission to open a cowshed, the entrepreneur had the right to make a sign and publication about the sale of milk and cows from this cowshed. It should be noted that persons wishing to have their own cowshed or dairy farm should report to the City Council. The cows on the dairy farms were examined by the city veterinarian, who entered the results of the inspection in the sanitary book, the form of which was established by the city administration. The book included the number of cattle and their content, cows, feed quality, vaccinations, tuberculin testing, diagnostic tests, and more. Cows in which an infectious disease was detected after a veterinary examination were not allowed to be kept in cowsheds. The owner recorded the number of cows in the cowshed in the register and periodically submitted a copy to the district veterinarian. All changes that occurred when moving animals in the cowshed were reported to the city veterinarian, who noted in his lists. Considerable attention was paid to the rules of building cowsheds. According to these rules, the building of cowsheds was not allowed in the yards of veterinary dispensaries and hospitals, factories, plants, on trading platforms, and cattle burial grounds, i.e. in places where there was a high probability of being animals with infectious diseases. When choosing places, it was allowed to build cowsheds at a distance of at least 5 yards $(10.7 \mathrm{~m})$ from them. The premises were built of any material, provided that it was stable. The walls of the cowsheds must be whitewashed and the rooms well ventilated. A stall of $13 / 4$ arshins (1.12 m) and 4 arshins long was allotted for one cow $(2.84 \mathrm{~m})$. The light area of the premises was not less than 1:12. The wooden floor on asphalt or cement base. It should be noted that keeping any other animals in the barn, except for goats, was not allowed. Such requirements for milk and dairy products in Kyiv were approved by the city administration for the prevention of tuberculosis among humans, the causative agent of which was transmitted during the consumption of milk from tuberculous cows. Veterinary and sanitary supervision of milk and dairy products 
was important and significantly complemented the veterinary and sanitary affairs of the Kyiv province in the late nineteenth-early twentieth century.

\section{Conclusions and future perspectives}

Veterinary and sanitary supervision in Kyiv began to develop only at the end of the $19^{\text {th }}$ century when city abattoirs were created, that is, a regulated institution was organized, where, in addition to preventing the pollution of water, soil, and air by slaughter waste, the task was to provide people with good quality meat and slaughter products. Initially, the responsibility for the observance and performance of these tasks rested with medical doctors, and later with veterinarians. In this regard, the veterinarians of Kyiv SlaughterhousesAcity abattoirs advocated that the slaughterhousesabattoirs should be subordinated to the Ministry of Internal Affairs. The separation of purely veterinary supervision from sanitary supervision (1899) forced the City Council to allocate a special subcommittee chaired by a member of the Sanitary Commission A. K. Stolpchevsky, which developed instructions for veterinarians responsible for veterinary and sanitary supervision at the Kyiv city slaughterhousesabattoirs. In addition to the slaughterhousesabattoirs, much attention was paid to veterinary and sanitary supervision of milk and dairy products, which significantly complemented the veterinary and sanitary activities in Kyiv in the late nineteenth and early twentieth centuries, after all, until 1914, the control of milk in the markets was carried out by sanitary doctors.

The prospect of further research is an in-depth study of the formation and development of veterinary medicine in Kyiv and Ukraine as a whole.

\section{Refernces}

Dostoievskyi, P. P., \& Khomenko, I. V. (1999). Zakonodavstvo Ukrayiny pro veterynarnu medytcynu [Ukrainian legislation on veterinary medicine]. Kyiv: Urozhay.

Dubrova, S. P. (1911). Kyevskye horodskye skotoboyny [Kyiv city abattoirs ]. Vestnyk obshchestvennoy veterynaryy, 5, 815-818.

Dubrova, S. P. (1911). Kyevskye horodskye skotoboyny. Vestnyk obshchestvennoy veterynaryy, 18, 966-969.

Korolev, V. K. (1914). K voprosu o snabzhenyy molokom naselenyya $\mathrm{h}$. Kyeva [On the issue of supplying milk to the population Kyiv.]. Veterynarna khronika Kyyivs'koyi huberniyi, 2, 128-162.

Kyevskye skotoboyny (1892). Vestnyk obshchestvennoy veterynaryy, 23, 376.

Kyevskye skotoboyny (1899). Vestnyk obshchestvennoy veterynaryy, 17, 624-325.

Novyy Kyevskyy yntsydent (1894). Vestnyk obshchestvennoy veterynaryy, 11, 322-324.

Ochah zarazy (1898). Kyevlyanyn, 183, 3.

Otchet Kyevskoho veterynarnoho likarya za 1893 rik (1894). Derzhavnyy arkhiv m. Kyyeva. F. 163. Op. 11. Ed. khr., 5, 28-31.

Protokol zasedanyya Horodskoy sanytarno-yspolnytel'noy komyssyy 17 yanvarya seho hoda (1914). Veterynarna khronika Kyyivs'koyi huberniyi, 1, 60-71.

Raport h. Kyevskomu Polytsmeysteru (1899). Derzhavnyy arkhiv Kyyivs'koyi obl. F.1. Op. 271. D. 394, 2-4.

Stopakevych, K. (1894). Pyatyletye (18871894) Kyyivs'ki hromads'ki boyi u veterynarno-sanitarnomu vidnoshenni [Five years (1887-1894) of Kyiv city abattoirs in veterinary and sanitary relations]. Vestnyk obshchestvennoy veterynaryy, 11, 332-336.

Stopakevych, K. (1894). Kyevskye obshchestvennye boyny $v$ veterynarno-sanytarnom vidnoshenni [Kyiv city abattoirs in veterinary and sanitary relations]. Kyevlyanyn, 80-81, 412-415. 
Stehney, M. M. (2008). Diyal'nist' Kyyivs'kykh mis'kykh riznyts' u kintsi XIX - na pochatku $X X$ st. [The activity of the Kyiv city abattoirs in the late 19th and early 20th centuries]. Naukovyy visnyk L'vivs'koho natsional'noho universytetu veterynarnoyi medytsyny ta biotekhnolohichnoyi imeni S. Z. Hzhyts'koho. L'viv, 10, 2(37)4, 187-192.

Tomylyn, Y. (1892). Kyevskye tsentral'nye horodskye skotoboyny [Kyiv central city ab- attoirs]. Vestnyk obshchestvennoy veterynaryy, 20, 313-314.

Uvedomlenye v Tahanrohskuyu Horods'ku Upravu vid 17.06.1906 №1324. (1906). Derzhavnyy arkhiv m. Kyyeva. F. 163. Op. 53. D. $200,9$.

Uvedomlenye $v$ Tombovskuyu Horods'ku Upravu vid 5 kvitnya 1902. (1902). Derzhavnyy arkhiv m. Kyyeva. F. 163. Op. 53. ED. khr. 112, 30.

\section{СТЕРНЕЙ М. М. (2020). СТАНОВЛЕННЯ І ОРГАНІЗАЦІЯ ВЕТЕРИНАРНО-} САНІТАРНОГО НАГЛЯДУ КИЄВА КІНЦЯ ХІХ - ПОЧАТКУ ХХ СТ. Ukrainian Journal

of Veterinary Sciences, 11(4): 79-88, https://doi.org/10.31548/ujvs2020.04.008

Анотація. Подано відомості щодо становлення ветеринарно-санітарного нагляду в м. Київ, починаючи з кінця ХІХ століття. До 1888 р. в Києві функиіонувало 17 невеликих приватних різниць, розкиданих по всьому місту. Різниці розміщувалися при дворах $i$ брудних коморах, де примітивно забивали худобу та не надавали значення ветеринарносанітарному нагляду. Ці різниці викликали велике незадоволення в міського населення й Київська міська дума вирішила закрити існуючі різниці і відкрити міські різниці, тобто сформувати регламентований заклад, який дотримувався б високогуманних завдань, відповідальність за виконання яких покладалася на ветеринарних лікарів.

Для з'ясування питань ветеринарно-санітарного нагляду на міських різницях у 1899 році виділено спеціальну підкомісію, головою якої обраний член Санітарної комісії А. К. Столпчевський. Підкомісією ставилося завдання розробити інструкцію для ветеринарних лікарів, що відповідали за ветеринарно-санітарний стан у Київських міських різницях, який проводила Санітарна комісія. Лише в 1899 року розмежовується нагляд суто ветеринарний від нагляду санітарного. Для правильної організації ветеринарносанітарного нагляду, в 1909 р. введено обов'язкові постанови, що включали правила влаштування й утримання різниць. Цими постановами було введено одноманітний порядок у різничу справу.

У 1900 році міський ветеринарний лікар М. К. Кобилянський запропонував розширити ветеринарний персонал у м. Києві і ввести обов'язкову постанову щодо утримання ферм і молочної худоби. Уперше в 1901 р., за резолючією Київського губернатора, у селищі Пуща Водиця почав функціонувати кумисно-кефрірний заклад, що був у підпорядкуванні ветеринарно-санітарного нагляду. Проте, постанова за наглядом за корівниками, молочними фермами, кумисними закладами й окремими господарствами, що займаються продажем молока й молочних продуктів ум. Києві, вийшла лише в 1916 році.

Ключові слова: міські різниці, ветеринарно-санітарний стан, різнича справа, контрольнотрихінельозна станція, молочна справа 